\title{
Confessional Lutheran commitment in the International Lutheran Council - A conservative contribution of Lutheranism to the Ecumenical Age
}

\begin{abstract}
Author:
Werner R.A. Klän ${ }^{1,2}$

Affiliations:

${ }^{1}$ Systematic Theology, Lutherische Theologische

Hochschule, Germany

${ }^{2}$ Department of Church History and Church Polity, University of Pretoria,

South Africa

Note:

Coming from the background of the Independent Evangelical Lutheran Church and its seminary, the Lutherische Theologische Hochschule Oberursel in Germany; having the honour of recognition by the Senior Appointment Committee of the University of Pretoria as an extraordinary professor in the Faculty of Theology beginning 01 January 2013; and finally having worked with the colleagues of the Lutheran Theological Seminary in Tshwane for the last five years, I would like to take the opportunity to share some of my thoughts on confessional Lutheran identity and its ecumenical commitment with the readers of HTS Theological Studies.
\end{abstract}

\section{Correspondence to:} Werner Klän

Email:

werner.klaen@gmx.de

Postal address:

Altkönigstraße 150, 61440

Oberursel, Germany

Dates:

Received: 11 Apr. 2013

Accepted: 26 June 2013

Published: 30 Sept. 2013

Read online:

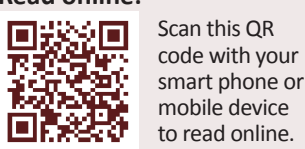

The contribution of confessional Lutheran churches, especially those affiliated to the International Lutheran Council of the ecumenical movement was regarded more or less as marginal, compared to the mainstream Protestant churches. Rooted in the 16th century Reformation, relating to the confessional writings of the Lutheran Church as comprised in the Book of Concord (1580), these churches in the 19th century rediscovered what might be labelled 'confessional identity'. Looking at the European scene as a paradigm of secularisation (in spite of necessary differentiations), it is observed how traditional faith, trying not to sever its biblical and confessional roots, approached and reacted to 'modern' developments in society and the church. A historical survey, combined with a systematic reflection on Lutheran identity in a post-Christian context, served to diagnose the problems of Christian responsibility in a globalising world. Through the changes and challenges that confront Christianity at the beginning of the 21st century, the confessional Lutheran churches - affiliated to the International Lutheran Council - came to face their ecumenical responsibility. The mission of the Church ought to be reconsidered in terms of its biblical foundation, its historical identity, its confessional self-understanding, and its ecumenical obligation.

\section{Sixteenth century Reformation and 19th century confessional Lutheranism as 'modern' approaches to the formation of the Church}

A historical truth that is apparent, and seems to me to be irrefutable is that: the Lutheran Reformation was in its time an academic theology, politically, and in many social areas, a forwardlooking, if not to say, a progressive movement (Johnson \& Maxfield 2012). The realisation that the reform of the Church, as effected by the Reformation, was concerned with the rediscovery of the gospel and the necessity of preserving the one church, does not alter this assessment. In my opinion it is undeniable that the confessional age which produced such important basic works as the Augsburg Confession and the Book of Concord (Kolb \& Wengert 2000), now an integral part - and next to the Bible - the main source of confessional Lutheran identity, made considerable, if not to say essential contributions towards modernising early modern society and forming states in Europe (Rublack 1992). ${ }^{1}$

The authors of the Lutheran Confessions ${ }^{2}$ were, of course, deliberately conscious of the contemporary character of the confessional writings of the 16th century, but at the same time deeply convinced that they were confessing the eternal truth of God's word (Kolb 1999). It is noteworthy however, that nearly all the Lutheran confessions were subscribed to by princes and other 'worldly' authorities. They were acting on behalf of their territories in defence of the Evangelical faith, and at the same time, justifying the ongoing Reformation process against the Pope and the German Emperor (Kolb 1991; Estes 2009). Although, due to the political conditions of their times, the Reformation movement(s) ended up in a state-church system (Boettcher 2008; von Friedeburg 2008; Lund 2008) which prevailed until the end of World War 1 (in Germany at least), the Lutheran churches emerging from the 16th century Reformation, particularly those which adhered to the Book of Concord, may be seen as an expression of emancipation from the political and ecclesiastical powers that had fought for the domination of Europe throughout the Middle Ages.

1.This insight was basically triggered by the results of the 1988 symposium of the Verein für Reformationsgeschichte, cf. Rublack (1992). 2.For the historical and theological background cf. Arand, Kolb and Nestingen (2012)

How to cite this article: Klän, W.R.A., 2013, 'Confessional Lutheran commitment in the International Lutheran Council - A conservative contribution of Lutheranism to the Ecumenical Age', HTS Teologiese Studies/Theological Studies 69(1), Art. \#1984, 10 pages. http:// dx.doi.org/10.4102/hts.v69i1.1984

Copyright: @ 2013. The Authors. Licensee: AOSIS OpenJournals. This work is licensed under the Creative Commons Attribution License. 
At the root of these 'modern' developments lies - amongst many other impacts and influences - Luther's distinction of the 'two kingdoms', or two realms (Estes 2012; Wright 2010), which provide a way for distinguishing between penultimate realities, values and goals on the one hand, and the ultimate destiny of human existence on the other. One might tend to blame Luther and the Lutheran confessions for having initiated, instigated and theologically legitimised the decline of what used to be 'Christian Europe' into secularisation. This process, however, was far more complex and cannot be reduced to a mono-causal and linear deduction (Taylor 2007:507). On the contrary, the Lutheran distinction of the two realms exonerates the Church by restricting its tasks to the proclamation of the Law and the gospel apart from ruling and regulating the affairs of state and society. This fundamental distinction, does not at all intimate that the Law of God would not apply to mundane matters, and thus the application of God's universal will would have no place in the proclamation of the Church; quite the opposite: the 'political use of the Law' has to be an integral part of the Church's message. ${ }^{3}$

But the Church, being according to its Magna Charta in Article VII of the Augsburg Confession the 'assembly of saints' commissioned to 'purely preach and teach the Gospel and to rightly administer the sacraments' (Kolb \& Wengert 2000:43; Augsburg Confession VII 1), does not strive for totalitarian domination of the world: 'For the Gospel teaches an internal, eternal reality and righteousness of the heart, not an external, temporal one', and 'does not overthrow secular government, public order, and marriage'(Kolb \& Wengert 2000:48-49; Augsburg Confession XVI, 4-5). Right from the outset, the Lutherans claimed that they did 'not understand the church to be an external government of certain nations'; rather, the true Christians were regarded as 'people scattered throughout the entire world who agree on the gospel and have the same Christ, the same Holy Spirit, and the same sacraments' (Kolb \& Wengert 2000:175; Apology of the Augsburg Confession VII \& VIII para. 10).

Therefore the ('New', or 'Old') Lutheran fathers and mothers of 19th century Germany, filled with the spirit of the revival, discovered the confessional inheritance of the Lutheran Reformation as the fulfilment of their longing for the gospel of sin and grace, for the saviour of sinners, and desired to preserve in an undiminished form for themselves and their posterity the heritage of Concord-Lutheranism from the 16th century. Hand in hand with this confessional assurance, they discovered the church as an organic, institutional, and communicative strength, in the framework of which their commitment to God's Holy Word and the Lutheran confession could take shape. They recognised that church services, confession and church constitution are integrally correlated. That is why they were prepared to make great

3.This was a prevalent idea in the theology of August Christian Vilmar, a staunch opponent to the state-church-system in the state of Hesse in the 19th century, cf. Klän (2002). Remarkably, August Vilmar's grandnephew, Friedrich Wilhelm Hopf being the director of Mission Lutherischer Freikirchen (Bleckmarer Mission) (today: Lutherische Kirchenmission, or Mission of Lutheran Churches [MLC] in South Africa) in the 1970s and 1980s of the 20th century, applied this concept to the situation of in the 1970s and 1980s of the 20th century, applied this conc
the mission churches in southern Africa; cf. Stolle (2013). sacrifices to maintain their belief, their confession, and their church (Klän \& Da Silva 2010).

It was no accident that the crystallization point of the confessional awakening, which led in the end to the emergence of independentevangelical Lutheran churches, was the Sacrament of Holy Communion. The concern that forced confessional Lutherans onto 'solitary paths' [Rocholl 1881] was that of preserving ... [what they regarded a] Biblical Lutheran understanding in an ecclesiastically binding form, of defending it in its exclusivity against every kind of false compromise. Thus, the question of church fellowship in the sense of fellowship in Word and Eucharist, including intercommunion and intercelebration, was the foremost concern in the creation of confessional Lutheran churches in ... [the 19th century]. It was these churches that created a new awareness of the ConcordLutheran principles of the sixteenth century and gave them renewed ecclesiological reality. They wanted to manifest Lutheran identity in the ecclesiastical dimension by establishing that, as the expression of full church fellowship, fellowship in public worship, particularly at the ... [communion table], has as its unconditional prerequisite a consensus in faith, doctrine(s), and confession. (cf. Klän 2006:139; Klän 2007)

These confessional Lutherans were at the same time protagonists of a new freedom of the church from state control and political subordination, in character with the gospel. In addition they were, at least in religious matters, pioneers fighting for social values of the modern era such as freedom of assembly, freedom of speech, and freedom of conscience. The founders of the Lutheran confessional churches in Europe, and those amongst them who emigrated to Australia, America, or Southern Africa, proved to be also contemporaries of the movement for bourgeois emancipation. This remains true even if we recognise that the theological content for which they were prepared to bring great sacrifices was principally conservative, and that the same held true for their political convictions. The claim for religious, ecclesiastical and theological independence in terms of confessional church bodies is nevertheless an integral part of their common heritage.

It has to be recognised, on the other hand, that these Lutheran movements never succeeded in regaining a major influence on the intellectual, spiritual, and religious developments in their respective lands. Whereas in most parts of Europe - except for France, which since the French Revolution preferred to define the republican constitution as 'laical' the state-church system inherited from the Constantinian era prevailed, these confessional movements and churches were, at least for some time, persecuted, driven underground and in the end - if acknowledged by the state - marginalised.

Thus, one could summarise that the transformation of the Lutheran heritage in the confessional Lutheran churches in the 19th century formed, in a manner of speaking, an avantgarde stance. They posed questions and found answers that, in their fundamental and permanent reference to Scripture, were also contemporary and appropriate. In this way they found the attention of their contemporaries, even if only to a certain degree. In many a regard, they positioned themselves against mainstream tendencies in theology and 
the church: this led to their marginalisation. They formed independent Lutheran church bodies in various German states, but - due to the perception that there was no future left for Lutheranism Europe - some of them went into exile to (northern) America (Barnbrock 2003:51-66), Australia (Silcock 2007), and southern Africa. Here, both the Lutheran Church in Southern Africa (LCSA) and the Free Evangelical Lutheran Synod in South Africa (FELSiSA) represent the heritage of confessional Lutheranism as it originated in 19th century Germany, and was delineated more intensely by inner-Lutheran conflicts (Reinstorf 2007; Hohmann 2011). These confessional Lutherans and the church bodies considered themselves to be Bible-based, church-committed Christians, and in this way, true adherents to the principles and positions of the 16th century Wittenberg Reformation.

These are member churches of the International Lutheran Council (ILC) and as such, they are 'committed to determining their decisions solely on the basis of the Word of God, and not on social, cultural, or practical considerations' (International Lutheran Council 2013). This goal, however, is much easier said than achieved. For there is a real difference between a respectably large Lutheran confessional church in a Christian western country with freedom of thought - like the Lutheran Church - Missouri Synod (LCMS) in the United States - and a minority church in a post-Christian context, such as Europe - like the Independent Evangelical Lutheran church (SELK) in Germany - or in a country with completely different religious orientation such as Japan, India, or China. It also makes a difference whether other Christian denominations and confessions have had a dominant role for many years or even centuries, like the Reformed churches in South Africa, or the Roman Catholic Church in South America, or whether a balance between, for example, Lutherans, Reformed Christians and Roman Catholics, exists. Moreover, the changes in the kind of Christianity that is emerging, especially in what is labelled the 'global south', cannot be neglected (Jenkins 2006, 2008b). The ILC and its member churches, taking their confessional Lutheran heritage seriously as their present-day obligation, ought to be a credible partner in dialogue with other churches and confessions, or movements and factions within major church bodies, that equally adhere to what might be defined as 'historic faith'. It cannot be overlooked, that in the past decades, the ILC has intended to distinguish itself from the Lutheran World Federation (LWF) by a clear-cut profile. All of its member churches take their confessional stance from the Book of Concord of 1580, whilst the LWF constitution explicitly mentions only the Augsburg Confession and Luther's Small Catechism amongst the confessions of the Lutheran church (Schjørring, Kumari \& Hjelm 1997:465-474). Tensions between these two major communities in Lutheranism worldwide exist in various areas of doctrine, such as Scripture, hermeneutics, the number, the role and the function of the Lutheran confessions, church fellowship, the ordination of women, the same-gender relationships, et cetera. It is noteworthy, however, that since 2003 the executive committees of both the LWF and the ILC have entered into consultations on a more or less regular basis (Böttcher 2007).

\section{Basic principles of confessional Lutheran identity \\ Lutheran identity: An ecclesiastical identity}

I believe that there is on earth a holy little flock and community of pure saints under one head, Christ. It is called together by the Holy Spirit in one faith, mind, and understanding. It possesses a variety of gifts, and yet is united in love, without sect and schism. Of this community I also am a part and a member. (Kolb \& Wengert 2000:437-438)

In this manner Luther elucidates the phrase 'the congregation of saints' (Kolb \& Wengert 2000:437-438) in the Large Catechism in his explanation of the third article of the Apostle's Creed.

\section{For Luther:}

it is of central importance to take seriously the existence of the church, or of 'Christendom', as he prefers to say [cf. Luther's deliberations on the translation of 'communio sanctorum' in the Large Catechism (Luther [1529] 2000:47-50, quoted in Kolb E Wengert 2000:436-437], and priority of the community of the faithful over one's own belief. This commitment to the church precludes identifying oneself as an atomized individual with one's own private belief[s] and piety and includes seeing oneself within a community of faith which is always prior to oneself and of which God the Holy Spirit makes use [of] for the accomplishment of His work. (Luther [1529] 2000:52-53, in Kolb \& Wengert 2000:438; Klän 2006:136)

This approach includes an ecumenical dimension as well. Lutherans understand themselves as being simultaneously evangelical, catholic, orthodox and ecumenical in the best sense of the word and professing a church which shall last forever: 'It is also taught that at all times there must be and remain one holy, Christian church' (Kolb \& Wengert 2000:42; Augsburg Confession VII, 1). Therefore, the renewal of the Church during the Reformation and after has repeatedly been accompanied by the recourse to the Scriptures, the origin and founding document of faith. For the gospel, the rediscovery and preservation of which were the primary concerns of the Reformation, is indeed the same gospel to which witness is given in the Holy Scriptures by the Apostles and the Prophets, besides which there can be no other Gospel (Gl 1:7). Thus, Lutheran identity is not first and foremost a special identity; it rather lays claim to catholicity (Arand 2012; Klän 2006:136) As in the Reformation, to renew the Church means to remain faithful to the one, holy, Catholic Church. (Notably, it was Nikolaus Selnecker, who, in the first edition of the Book of Concord labelled the early Christian creeds included in it: 'Tria Symbola Oecumenica - The Three Ecumenical Creeds' [cf. Kolb \& Wengert 2000:19]). Thus, the Lutheran reformers raise the claim of ecumenical entitlement and take ecumenical responsibility for the doctrine stated in their confessions. It is therefore of great importance to reach an understanding, to establish a 'consensus', about what in fact this gospel is, and that with the intention of proclaiming it: 
It is enough for the true unity of the Christian church that the gospel is preached harmoniously according to a pure understanding and that the sacraments are administered in conformity with the divine Word. (Kolb \& Wengert 2000:42; Augsburg Confession VII, 2)

If therefore the Church comes about through the preaching of the Gospel and the administering of the sacraments, then the following holds true: What is necessary for the unity of the Church is that which constitutes the essence of the Church. The converse is likewise true: What constitutes the essence of the Church is that which is required for its unity (Klän 2007:16). This approach will always be the basic principle for Lutheran endeavours in the realm of ecumenism for the:

existence and the unity of the church depend[s] upon one and the same thing: upon the Gospel in the form of the proclamation of the Word in accordance with the Scripture, and upon the Sacraments in the form of administration in conformity with their institution. ... [Herein consists] the identity of the Lutheran church and, as a consequence, the standard for the practice ... and ... [manifestation] of church fellowship. (Klän 2006:136-137; European Regional ILC Conference 2007; Klän 2007; Nafzger 2007; Rosin 2007)

\section{Lutheran identity: A common understanding of Scriptures}

The Lutheran confessions as included in the Book of Concord of 1580 are not intended to be anything other than a rendering of the scriptural truth, concentrated on the Gospel. Therefore, the Gospel and the 'doctrine' of the Gospel are:

not understood as a collocation of correct propositions, but rather the Gospel [is] understood as an event in which God imparts himself, in which God communicates himself to man and indeed salvifically, to man who has broken off the communication with God and, for the reason that he has broken it off, is not in a position to reestablish communication on the strength of his own efforts. (Klän 2006:141; cf. Bayer 2008:29-43; Fagerberg 1988:46-62)

The actual meaning and significance of the Gospel, which shines through in the emphasis on its effectualness in actu, is in conformity with both the New Testament and the confession of faith of the Lutheran Reformation. Hence the confession focuses on the centre of the Scripture, namely the Gospel, of which Jesus Christ is the quintessence and the living reality (Klän 2006:141; cf. Bayer 2008:68-94; Gassmann \& Hendrix 1999:48-84).

It is nevertheless true that the confession of faith, and no less the (Lutheran) doctrinal confession, is an introduction to the Scriptures and at the same time centres the Scripture from within the Scripture. This movement has indeed an unavoidably self-referential structure. Hence it is correct to speak of a 'hermeneutical circle': the confession of faith arises from the Word of God in Holy Scripture and leads back into it, however:

it is necessary to ensure that the Word of Scripture is and remains prior to the word of the confession. And to this extent one can even say that the confession of faith is constitutive for the church, albeit only in this derivative sense. (This standpoint tended to be viewed for quite some time in Protestant theology as 'confessionalistic', that is, as an embarrassment [and this perception may still be valid up to the present]). Klän (2006:142)

But then it must be ensured that the confession of the Church is and remains subject to the judgement of Scripture, as has been formulated in a lastingly valid manner by the Summary Concept of the Formula of Concord:

First, we confess our adherence to the prophetic and apostolic writings of the Old and New Testaments, as to the pure, clear fountain of Israel, which alone is the one true guiding principle, according to which all teachers and teaching are to be judged and evaluated. (Kolb \& Wengert 2000:527)

All in all: The confession focuses on the Scriptures and within the Scriptures on the focal point of the Gospel (Kolb 1991:132-137).

\section{Lutheran identity: Its existential dimension}

It is therefore:

both meaningful and helpful, not least in the sense of making certain of one's own identity, to also revert to texts that are several hundred years old, ... [these] can be and are intended to be a guideline for the understanding of what Christian faith is, what Christian life is, ... [in other words] how we can exist and lead our lives in the sight of God. Since the answers that can be found in the condensed form of the confessional documents of the sixteenth century (can) have a high degree of plausibility even for today's contemporaries, they offer at the very least guidance for communicating faith today as well - Christian faith in its significance for our contemporaries. (Klän 2006:141; cf. Slenczka 2003)

Accordingly, the Lutheran confessions of faith are not simply 'instruction about' the Gospel - propositions and theory nor are they merely an 'introduction to' the gospel. Rather, they are a guideline for making practical application of the Gospel in order to cope with certain existential situations, pre-eminently that of the human being standing as a sinner before God. To this extent, the confessional texts constitute a guideline even for pastoral care, and thus in a decidedly not abstract manner. The confessions of faith circumscribe and define a sphere, a framework, in which ecclesiastically legitimate proclamation is possible (Kolb 1991). It is a notable characteristic of the Lutheran Church that, unlike the Roman Catholic Church (even after the Second Vatican Council), anything along the lines of a papal magisterium is foreign to it. That means that there are no single authorities that, as such, have monopolies of interpretation (cf. Klän 2006:145; Bayer 2008:58-74).

A truly confessional stance is by no means just a retreat to distant historical documents; as a recourse to the Scripture it functions a guideline for the profession of faith. This can be shown in the Lutheran confessions themselves, for example, in Luther's catechisms. A fine illustration of this can be found in the reformulation of Luther's question 'What is this?'4 in the Small Catechism (Kolb \& Wengert 2000:351-358, passim). In terms of a modern language game: one can express the Commandments, the articles of the Creed, the petitions of the Lord's Prayer. 
question 'What is this?', which forms the introduction to the explanations in the Small Catechism, in existential terms and ask, 'How does this affect you?', or 'What does this say about you?', or 'Where do you recognise yourself here?' (Slenczka 2003:30; Klän 2006:146). For example:

I believe in God, the Father Almighty, maker of heaven and earth. 'What does this say about you? 'I believe that God has created me.' 'I believe in Jesus Christ our Lord, the only begotten Son of God.' What does this say about you? 'I believe that Jesus Christ is my Lord, who has saved me in order that I may belong to Him'. (Slenczka 2003:30-31; cf. Arand 2000)

The confession of faith functions as a guideline for the act of confessing one's faith. The transfer into our times - which is the duty of the Church through proclaiming the Law and the Gospel to this time and world - has already been accomplished and set down in an exemplary manner (Slenczka 2003:31). Exactly in this way, confessional statements:

constitute a guideline for actual confessing, statements that articulate an understanding of Christian existence and Church life that is at ... [the same time] Scriptural and contemporary just by proclaiming the will of God and by communicating the Gospel. (Klän 2006:146; Arand et al. 2012:1-12, 281-82)

\section{Observations from a European context \\ Critique of ideology}

In his book Dis-enclosure: The deconstruction of Christianity, Jean-Luc Nancy (2008a:237) maintains: 'We do know, that our entire tradition is Christian, that our provenience is Christian. ${ }^{5}$ At the same time, he claims that Christianity itself, Christianity as such be passed, because it finds itself in the state of being passed' (2008a:241). This is what he labels (2008a:242) 'de-Christianization', nevertheless observing that 'Christianity and Occident are inseparable.' In this respect, Nancy (2008a:244) underscores that the 'modern world' is nothing but the 'becoming of Christianity/Christendom.' To 'deconstruct' Christendom in this sense does not mean to destruct Christendom, but to break down, dismantle, loosen its inner composition. Nonetheless, Nancy (2008a:253) is well aware that 'Christianity/Christendom is exactly the opposite, the negation, the rejection of any deconstruction, including its own deconstruction', because it 'exists essentially in the proclamation of the end.' This leads, in Nancy's philosophical conclusion, to the concept of 'openness as the horizon of meaningorsense (Sinn)', because, as he sees it, Christendom aims at constituting 'pure' meaning or sense. This 'future of Christianity/Christendom' will ultimately be an atheism that asserts its 'Christian' origin, and it expires in the 'end of promise of meaning/sense' (2008a:241). Nancy (2008a:244) then - which does not happen unexpectedly - decidedly opposes a perception that it was an intrinsic disintegration of Christianity or Christendom that delivered western societies to their modern errors. This means indicating that 'asking the question, "to what extent we are still Christian", brings us to the utmost end of Christianity/Christendom' (2008a:242). This is the philosophical comprehension, or rather: the ideological conclusion of a fundamental 'reversal' in thinking translation; for the English edition see Nancy (2008b). about God. From a theological perspective, the intrinsic error of this concept lies with the assumption that the fate of Christianity is identical to the fate of meaning/sense' (Nancy 2008a:241). Christianity is regarded as a mere movement or structure of mentality, which can, in its development and tendencies, be analysed according to an internal logic. But this means abstracting from the reality of a living God - even if in the way as Nancy (2008a:263) interprets the idea of a 'living God', as a cipheror code of openness. This renunciation consequently manifests itself in many ways, the crassest of which is evident in the fact that man suffers under the delusion that he is lord of himself - or even the whole world - whilst in reality his toil and effort only revolve around himself (Kolb 2005). This is really the most devastating of all human delusions (Jüngel 1999:75, 93, 108111), which characterises the outlook of the modern Western mind since the Enlightenment, and represents - from a biblical-theological standpoint - a false notion of autonomy, or rather, a false concept of 'freedom' closely bound up with the notion of autonomy. At the core of this struggle for what allegedly autonomous human beings believe to be 'freedom' is the delusion of being able to invigorate and master one's own life - without God.

In the European history of ideas, as long as it was moulded by the biblical-Christian heritage and tradition, the norm of human life was God himself in his holiness and sovereignty (Ex 34:6b-7). He creates human existence and places human beings in relation to himself in such a way that they would speak to and answer him, that is, be accountable (Kolb 1993:48-59). In this way, an immutable distinction between God and human beings, between creator and creation, is established (Kolb 2012:5-12).

This distinction cannot be denied, disregarded, or ignored without causing damage or destruction to God's wellintended and salutary purpose for humankind (Kolb 2012:6573). Thus, the unchangeable will of God, as expressed, for example, in the Ten Commandments, aims at nothing else than that humans should live as God's creatures, in the way that God has intended and determined them to live, and not to take themselves for God, the Creator - that is, 'as human beings among human beings in a shared and God-given world' (Wenz 1998:630-31, author's own translation). Thus, God's commandments are primarily beneficial directives and helpful precepts; however, they are also critical standards for human life and conduct (Kolb 1993:106-121).

Neglect or even contempt of the God-given standards, as they are to be found, for example, in the Decalogue, may seem to be particularly prominent in societies shaped by postEnlightenment mentalities. Nevertheless, God's admonition against 'covetousness' unmasks the addictive disposition of any sinner's attitude: selfishness, avarice, greed, craving for recognition and a great number of material or mental addictions (cf. Schaef 1987). But these tendencies are by no means restricted to what might be regarded a decadent, western, European mindset. Sinful phenomena may differ in the way they manifest themselves, and they may vary in their 
frequency of occurrence, depending on the societal, religious, political, legal, or moral conditions in various contexts - but they will most certainly never be excluded, or become nonexistent.

\section{Glimpses at the religious landscape in Europe}

\section{A general survey}

The religious landscape of Europe is highly diversified: The north is predominantly (mainstream) Lutheran, with a statechurch system in the Scandinavian countries (Denmark, Sweden [until January 01, 2000], Norway, Finland) that originated in the Reformation and prevailed mostly to the end of the 20th century. In the northeast, we find the Baltic countries with Latvia being predominantly Lutheran, but also hosting a considerable Russian-Orthodox minority; in Lithuania, about $70 \%$ of the population belong to the Roman Catholic Church, where as the Lutheran church comprises about 20000 members; in Estonia the majority of Christians belong to the Lutheran church, whilst the Roman Catholic Church forms a minority. In the south and the south-west Roman Catholicism is prevalent (Italy, Spain, and Portugal). In the west of the Continent, France and Belgium are mostly Roman Catholic, but in a rather secular variation; the Netherlands are largely Calvinist, with the Lutherans having entered into a merger of a Protestant Church. In Great Britain, the Church of England still incorporates the majority of the population in England, whereas in Scotland the Calvinist tradition prevails. Ireland (excluding Ulster) is mainly Roman Catholic, Iceland predominantly Lutheran. To the east, Poland is largely and staunchly Roman Catholic, Belarus, the Ukraine, and Russia are covered by their respective (Eastern-) Orthodox Churches. The southeast (major parts of the Balkans, Greece), also is primarily (Eastern-) Orthodox. In Central Europe, Switzerland is the home of the Reformed Church; in Austria, due to the success of the Counter-Reformation, the Roman Catholic Church comprises the major part of the population. With regard to the diversity of the denominational, ecclesiastical, constitutional, national conditions across Europe, it seems to me difficult to summarise a diagnosis of what Philip Jenkins (2007:53) labels 'European Christianity' (cf. Müller-Graff \& Schneider 2003, passim).

The self-perception of Europe as a political union is obviously secular. It is no contradiction to this fact that politicians from the spectrum of the conservative parties - by no means all of them! - as well as representatives of the Christian churches, would claim the roots of European history and the profile of European identity to be fundamentally Christian, JudeoChristian, Greco-Christian, or Judeo-Greco-Christian. For instance, when the negotiations aiming at drafting a European Union Constitution were in progress, ${ }^{6}$ the major Christian churches, even with support from some of the Christian Democratic parties in Europe, did not succeed in introducing a reference to God or to the Christian heritage in Europe into the drafts (Läufer 2005:34). As the national

6.Cf. European Union (2004), 'Treaty establishing a constitution for Europe', Officia Journal of the European Union 47,9; this draft was never formally received, rather Journal of the European Union 47, 9; this draft was never formally receive
superseded by the 'Lisbon Treaty' of 2007; cf. European Union (2007). self-concept in France is basically laical, there was no chance whatsoever for such an approach to succeed, although it was not just the Roman Catholic Church trying to advocate this idea (Lehmann \& Kock 2002; Evangelischer Pressedienst 2003).

Lutherans, however, should bear in mind that Luther himself, at the peak of the influence of the Reformation movement, at a time when $98 \%$ of the European population were baptised Christians, diagnosed that 'among thousands, there is scarcely a single true Christian'(Luther [1523] 1962:91). Interestingly, Luther at this point does not apply ethical or moral standards or church membership to support his judgement, rather he makes use of a truly biblical criterion, namely true faith.

\section{The Islamic challenge}

Since the late 1950s, the Muslim portion of the European populations has recorded an increase in growth. Guest workers from Turkey were called to Germany in order to support the German post-World War 2 'Wirtschaftswunder' [economic miracle] with their manpower. In France, most inhabitants of the former French colonies are allowed to hold French passports; immigration to the economically attractive 'mother country' is therefore no big issue. The situation in the Netherlands is similar, where immigrants from Indonesia form the significant group of foreign citizens. In addition, refugees and asylum seekers, also from countries with a Muslim identity, are found all over Europe. It can be easily shown that the birth rate of the immigrant part of the population exceeds the birth-rate of the long-established European population (Jenkins 2007:1-26).

In France, for example, the laical self-definition of the nation energetically opposes the wearing of the burka; the Belgian government has already imposed a ban on the wearing of the burka, and the Roman Catholic bishops of Switzerland have made a suggestion to do so as well (Brotz 2010). The reasons for these vary: one is the obvious demonstration of religious convictions in public; another one claims to protect the dignity of women. Nevertheless, it is hard to assess future developments. And in general, it is rather difficult to judge which of the various organisations that claim to represent 'the Muslims' in a given country really are in a position to speak on behalf of their fellow-believers. What is more alarming, is the fact that in various countries across Western Europe, like Great Britain and Germany, we find converts to Islam who are prepared to join terrorist organisations and get drilled in training camps in order to perform assaults in their home countries, and thus engage in jihad; these are the so-called 'home-grown terrorists.'

Here a few examples from the German situation: the German Federal Government has started to convene a 'German Islam Conference', presided over by the Minister of the Interior, in order to support a political-societal dialogue with Muslims and to strengthen their societal participation (Deutsche Bundesregierung 2010). One of the goals of the political leaders is to impede any tendencies towards self-isolation in 
the Muslim contingent in Germany (Reinkowski 2012; Zander 2012). Another goal is the introduction of Islam religious education in the state school system (which covers more than $95 \%$ of the primary and secondary educational system in Germany) in order to avoid an uncontrolled religious indoctrination in the Qur'an schools which are connected to the mosques and the mullahs and do not form a part of the official school system.

Lutherans, however, and Christians in general I imagine, should be very aware of the fact that it was Luther, who staunchly opposed any attempt to crusade against the Turks - as the then representatives of Islam - although he regarded it as legitimate that the Emperor and the princes of the Holy Roman Empire of the German Nation defended the Empire and their territories against the aggression of the Ottoman troops in the late twenties and thirties of the 16th century, and concluded that in this case, the population was obligated to support this armed conflict as defensive warfare (Ehmann 2008; Francisco 2007; Lexutt 2011). On the other hand, Lutherans and Christians in general, ought to remember that Islam, according to the Augsburg Confession, is judged to be an anti-Trinitarian heresy rejected in the first article of the Creed (Kolb \& Wengert 2000:36; Augsburg Confession I, 5).

It has to be deplored, nevertheless, that Christian churches in Europe, and Lutherans in particular, have done almost nothing in order to develop missionary strategies for Muslims. According to the German Constitution (Deutscher Bundestag n.d.), religious freedom has to be granted also to Muslims. Since the late 1990s, missionary activities in the city of Leipzig have been reaching out to Muslim migrants - mostly from Iran - who form a considerable group within the Lutheran congregation celebrating their services in Farsi. In the meantime, a full-time missionary of the Mission of Lutheran Churches is working there. Obviously, these endeavours are but a drop in the ocean. ${ }^{7}$

\section{Changes after the fall of the Iron Curtain}

In many ways, the situation in the East of Europe is different from that in the West (Müller \& Pollack 2007). In some parts of the East, where churches and Christians had been marginalised and oppressed by the communist rulers, the newly-gained freedom after the end of the Soviet rule allowed the churches to re-establish themselves; in various countries, they were given back their property, churches, parsonages, schools, et cetera. Time and again, this led to major problems in terms of restoring or sustaining the buildings. Restrictions to the (re-) organisation of church bodies ceased to exist with the exception, for example, of the repressive situation in Belarus (Schön 2011) - and access to the study of theology at the state universities was no longer impeded (Pollack, Borowik \& Jagodzinski 1998). This again caused different kinds of challenges. Much to the disdain especially of the Orthodox churches that are used to regard themselves as unrivalled 'churches of the country' (Hallensleben 2009;

7.One might mention the initiative taken by the Lutherische Kirchenmission (Bleckmarer Mission) in the city of Leipzig, where migrants from Iran are being taken (Bleckmarer Mission) in the city of Leipzig, where migrants from Iran are being taken
care of in many ways, cf. Gevers (2012); Lamprecht (2006); Zieger (2012), cf. the activities of Rev. Dr Martti Vaahtoranta (2005) and Vaahtoranta (2008).
Kyrill 2009), various protestant denominations, including Lutherans, have started to evangelise in Eastern Europe. They are usually seen as intruders.

The fall of the iron curtain, at the very latest, has made us aware that the eastern parts of Germany, which had been under socialist rule until 1989 and cover the heartland of the Reformation, are sorely in need of mission (Petzold 2007; Pollack 2009; Wohlrab-Sahr 2007). The need for mission work holds true also for France, which has long been a secular state and in its national ideology maintains that it is laical on purpose, for Belgium and the Netherlands, as for the Czech Republic and Hungary. For example: in Eastern Germany and the Czech Republic, active Christians account for around $10 \%$ of the population. In the traditionally Roman Catholic countries such as Portugal, Spain, Italy, Ireland and Poland, the situation is in some respects different (Kasper 2007), and the same holds true for Greece and for Russia with their traditionally (Eastern) Orthodox majorities. But even in those countries, a growing detachment from the Christian walks of life, church attendance, traditional moral standards, once common ethical rules, under pressure from secularisation, globalisation, or 'Westernisation', can be observed (Pollack et al. 1998).

\section{The Charta Oecumenica (COe 2001)}

Right at the beginning of the millennium, the Conference of European Churches and the Congregation of European Bishops (CCEE) (2001) published the Charta Oecumenica: Guidelines for the growing cooperation among the churches in Europe which was signed on April 22, 2001. According to this document, the European churches are to work together more intensely. In particular it is hoped that there will be a deeper understanding between the churches, reconciliation and a strengthening of the ecumenical movement. In part this document reflects the greatly changed political situation in Europe since the late 1980s. In addition, it is an attempt to stand together in the face of increasing secularisation in Europe. In the Charta Oecumenica (2001), therefore, the preamble refers to Christ's prayer in John 17: '... that they all be one.' The conclusion drawn from this quotation is that 'we must strive to overcome the divisions still existing among us, so that together we may credibly proclaim the message of the gospel among all people' (Charta Oecumenica 2001). On the contrary, 'fundamental differences in faith', and 'schisms, hostilities and even armed conflicts' are not concealed.

It is noteworthy that this document is not designed to function in a 'magisterial or dogmatic' manner. Nevertheless, for some, it claims authoritative respect which originates in 'voluntary commitments of the European churches' (Charta Oecumenica 2001). But it does not lack honesty when stating: 'A particularly painful sign of the divisions among many Christians is the lack of Eucharistic fellowship.' Thus, with regard to the fact that there are different views of the church and its oneness, of the sacraments and ministries', the charter clearly states that in order to manifest church 
fellowship, 'endeavours to reach a consensus of faith must be continued at all cost. Only in this way can church communion be given a theological foundation.' Cooperation between various churches and denominations is restricted to the presupposition, 'wherever conditions permit and there are no reasons of faith or overriding expediency mitigating against this Charta oecumenica 2001' (Charta Oecumenica 2001).

The third part of the charter, 'Our Common Responsibility in Europe', places a strong accent on the social and ethical values arising from Western - and in many ways Christian - history. In this rather political context, the goals of 'strengthening community with Judaism' and - formulated prior to 9/11 'cultivating relations with Islam', plus 'encountering other religions and world views', given the 'plurality of religious and non-confessional beliefs and ways of life' as a 'feature of European culture', must be considered (Charta Oecumenica 2001). Amongst the values valid for European integration, as seen from a Christian position, the heritage of Christian monotheism is noted, as it has set forth the principles of freedom of conscience and religious freedom.

What is most convincing in this document is the selfobligation of the undersigned churches 'to defend the rights of minorities and to help reduce misunderstandings and prejudices between majority and minority churches in our countries' (Charta oecumenica 2001). Thus, the Charta Oecumenica provides an honest, solid platform to meet the challenges and fulfil the (self-imposed) obligation of contributing to ecumenical endeavours and religious discourse on an equal footing.

\section{The task of the Church Basic assumptions}

It remains the task of the Church to proclaim this very 'just and immutable will of God' (Formula of Concord, Solida Declaration V 17, in Kolb \& Wengert 2000:584) for his world and its population in a manner that is relevant for today. The Church is thus obligated to be critical of her contemporary setting. Contemporary life also affects the Church and its members. One cannot deny that the Church is influenced and affected by societal 'trends' and tendencies. These movements not only find expression 'outside of and around' the Church, but also creep into the Church.

Therefore, the Church should deal critically with contemporary issues. When Christians do so, this demonstrates that they are aware of being inevitably connected with their context. If the Christian message is to be credible, the Church will speak what it has to say to the world outside of her doors, first to itself. The Church, along with each of its members, must also admit and confess, personally and corporately, the misdeeds and failures which go against the divine standards. The real debate on sexual abuse committed by priests and church workers, and in church institutions, youth camps, schools, et cetera, may well serve as proof for this concept. Repentance will never invalidate the Church's credibility but strengthen it, so long as the Church speaks out of humility - which derives from a recognition of its own failures and fallibility - rather than with an attitude of arrogance.

If the Church does this, it will be able to address those issues in all nations and times where the divine standards of God's will have been abandoned, despised, or wantonly rejected. The Church will today warn, and where necessary, even accuse. Christians and the representatives of the Church speak to situations where the validity of the divine standards is being foundationally or practically challenged. Christians and the Church will then provide realms and rituals for reconciliation (Wüstenberg 2004:668-671; Wüstenberg 2009), and they always do such with the goal of calling human beings back into the fellowship and freedom which God preserves and offers in himself.

\section{Theological challenges}

At present, it does not seem likely that a major awakening will stir up European Christians, churches, or societies in the near future. All church bodies in Europe face the challenge of 're-Christianising' areas that have been 'de-Christianised' (Rosin 2007), utilising for this purpose also models of cooperation in altar and pulpit fellowship, inter-celebration, and intercommunion. Especially with regard to ethical challenges, Christians and Christian churches ought to strive to respond to those with one voice as, for example, the Charta Oecumenica (2001) suggests.

On the other hand, from the basic theological propositions laid down in the Lutheran understanding of the theology of the two kingdoms or realms (Bayer 2008:120-153, 309-325), one might question a concept of 'Christianity' intended to 'provide a guiding political ideology for much of the world', as Jenkins (2002) seems to propose. With the historical experience of totalitarian systems in 20th century Europe and not only there - at the backs of their minds, Christians ought to be very careful in fostering a 'political theology' that would aim at the domination of the world's morals. For in contrast to Jenkins's position, I am deeply convinced that the 'First Christendom' is not 'the politico-religious order that dominated Europe from the sixth century through the sixteenth' (Jenkins 2002). Rather it is the 'little flock' that Jesus addresses in the Gospel, telling it to 'not be afraid, for your father is pleased to give you the kingdom' (Lk 12:32), which at its core, is a spiritual reality.

It is far more likely that, at least in Europe, Christianity - or rather the Church - will take a shape similar to the one it had throughout the first three centuries - being a minority, despised, mocked, marginalised, suspected, neglected, displaced, persecuted and even killed. It has always been seductive to Christians - and to church leaders in particular - to see the Church as a culturally, politically, morally influential and even predominant factor or institution in this world. That tempting dream, that in some realms of Christianity still lingers on, belongs most intimately to the imperial ideology and ecclesiastical enthusiasm of the Constantinian era (Jenkins 2008a). 
Coming from a post-Christian environment, I have learned that for the mission of the Church, it is most necessary for the Church to cling faithfully to its biblical roots and to assure itself of its historical and even confessional identity. And if it holds true that Christianity is in the process of moving from the north-western hemisphere to the south and the southeast, or that it is emerging there - for to a certain degree, one might accept some of the propositions made in Jenkins (2006) - then Christians in Europe are undoubtedly obligated to take part in dialogue with the emerging southern churches about what was once given to the northern hemisphere in the theological legacy of the fathers of the Early Church, like Cyprian, Athanasius and Augustine - Africans all of them. Moreover, in the era of globalisation, the northern churches will have to listen very carefully to what the emerging churches in the South have to say on Christian identity and authenticity.

One thing, as it seems to me however, is undoubtedly in force: according to the Christian faith, human freedom is nothing other than a response (Bayer 1995:74), a thankful reply, accomplished through the self-sacrificing work of Jesus Christ for the sake of human redemption. In this sense, the call back to God, the call for responsibility and accountability before God, is nothing else than a call to freedom: the freedom of the children of God.

\section{Acknowledgements Competing interests}

The author declares that he has no financial or personal relationship(s) which may have inappropriately influenced him in writing this article

\section{References}

Arand, C.P., 2000, That I may be His own: An overview of Luther's Catechisms, Concordia Academic Press, St. Louis.

Arand, C.P., 2012, 'The legacy of Leuenberg and Lutheran identity', in W. Klän \& G. da Silva (eds.), Die Leuenberger Konkordie im innerlutherischen Streit: Internationale Perspektiven aus drei Konfessionen, pp. 59-73, Edition Ruprecht, Göttingen.

Arand, C.P., Kolb, R. \& Nestingen, J.A. (eds.), 2012, The Lutheran Confessions: History and theology of the Book of Concord, Fortress Press, Minneapolis.

The Augsburg Confession [1530] 2000, in P. Kolb \& T.J. Wengert (eds.), The Book of Concord: The confessions of the Evangelical Lutheran Church, pp. 27-105, Fortress Press, Minneapolis.

Apology of the Augsburg confession [1531] 2000, in R. Kolb \& T.J. Wengert (eds.), The Book of Concord: The confessions of the Evangelical Lutheran Church, pp. 107-294, Fortress Press, Minneapolis.

Barnbrock, C., 2003, Die Predigten C.F.W. Walthers im Kontext deutscher Auswanderergemeinden in den USA. Hintergründe - Analysen - Perspektiven, Verlag Dr. Kovač, Hamburg.

Bayer, O., 1995, Freiheit als Antwort. Zur theologischen Ethik, Mohr Siebeck, Tübingen.

Bayer, O., 2008, Martin Luther's theology: A contemporary interpretation, Eerdmans, Grand Rapids.

Böttcher, R., 2007, 'Lutherisches Erbe im Widerstreit. Zur Beziehung zwischen dem Internationalen Lutherischen Rat und dem Lutherischen Weltbund', in M. Plathow (ed.), Lutherische Kirchen. Die Kirchen der Gegenwart 1, pp. 323-343, Vandenhoeck \& Ruprecht, Göttingen. (Bensheimer Hefte 107).

Boettcher, S.R., 2008, 'The social impact of the Lutheran reformation in Germany', in R. Kolb (ed.), Lutheran ecclesiastical culture, 1550-1675, pp. 305-360, Brill, Leiden/Boston. http://dx.doi.org/10.1163/ej.9789004166417.i-533.36

Brotz, S., 2010, 'Kurswechsel: Schweizer Bischöfe sind jetzt für ein Burka-Verbot', in Aargauer Zeitung, viewed 15 June 2013, from http://www.aargauerzeitung. $\mathrm{ch} /$ schweiz/kurswechsel-schweizer-bischoefe-sind-jetzt-fuer-ein-burkaverbot-8633882

Conference of European Churches and the Congregation of European Bishops (CCEE) 2001, Charta Oecumenica: Guidelines for the growing cooperation among the churches in Europe, viewed 25 March 2013, from http://www.ceceurope.org/ current-issues/charta-oecumenica/
Deutsche Bundesregierung, 2010, Jahresbericht der Bundesregierung 20092010, viewed $28 \mathrm{March} 2013$, from http://www.bundesregierung.de/
statisch/jahresbericht/Webs/Breg/jahresbericht/DE/SozialerFortschritt/ statisch/jahresbericht/Webs/Breg/jahr

Deutscher Bundestag, n.d. Grundgesetz, Artikel 137 (Weimarer Verfassung), viewed 28 March 2013, from http://www.bundestag.de/bundestag/aufgaben/ rechtsgrundlagen/grundgesetz/gg_11.html

Ehmann, J., 2008, Luther, Türken und Islam: Eine Untersuchung zum Türken- und Islambild Martin Luthers (1515-1546), Gütersloher Verlagshaus, Gütersloh.

Erlanger, S., 2011, 'France enforces ban on full-face veils in public', The New York Times, viewed 25 March 2013, from http://www.nytimes.com/2011/04/12/ world/europe/12france.html?_r=0

Estes, J.M., 2009, 'Luther and the role of secular authority in the reformation', in T.J. Wengert (ed.), The pastoral Luther: Essays on Martin Luther's practical theology, pp. 355-380, Eerdmans, Grand Rapids.

Estes, J.M., 2012, 'Clergymen, princes, and Luther's agenda', in A.M. Johnson \& J.A. Maxfield (eds.), The reformation as christianization, pp. 125-139, Mohr Siebeck, Tübingen.

European Regional ILC Conference, 2007, 'Thesen zur Kirchengemeinschaft. Entschließung der Teilnehmer der European regional ILC conference (Antwerpen, Entschließung der Teilnehmer der European regional ILC conference (Antwerpen, kirchlicher Verbindlichkeit. Erwägungen zum Weg lutherischer Kirchen in Europa kirchlicher Verbindlichkeit. Erwägungen zum Weg lutherischer Kirchen in
nach der Millenniumswende, pp. 27-28, Edition Ruprecht, Göttingen.

European Union, 2004, Treaty establishing a constitution for Europe, viewed 25 March 2013, from http://www.eurotreaties.com/constitutiontext.html

European Union, 2007, The treaty of Lisbon amending the treaty on European Union and the treaty establishing the European community, viewed 25 March 2013, from http://europa.eu/lisbon_treaty/full_text/index_en.htm

Evangelischer Pressedienst, 2003, Kirchen fordern Erwähnung des Christentums in EU-Verfassung, viewed 28 March 2013, from http://www.ekd.de/aktuell presse/ news_2003_12_04_1_kirchen_eu_verfassung.html

Fagerberg, H., 1988, A new look at the Lutheran Confessions, Concordia Publishing House, St. Louis.

Formula of Conocord [1577] 2000, 'Solida Declaratio', in R. Kolb \& T.J. Wengert (eds.), The Book of Concord: The confessions of the Evangelical Lutheran Church, pp. 524-660, Fortress Press, Minneapolis.

Free Evangelical Lutheran Synod in South Africa (FELSiSA), Homepage, viewed 25 March 2013, from http://www.felsisa.org.za

Francisco, A.S., 2007, Martin Luther and Islam. A study in sixteenth-century polemics and apologetics, Brill, Leiden. http://dx.doi.org/10.1163/ej.9789004160439.i-260

Gassmann, G. \& Hendrix, S., 1999, Fortress introduction to the Book of Concord, Augsburg Fortress, Minneapolis.

Gevers, H., 2012, 'Zwei wichtige Feste in Leipzig', in Info aus der Lutherischen Kirchenmission, viewed 27 March 2013, from http://lutherischekirchenmission. wordpress.com/2012/08/20/zwei-wichtige-feste-in-leipzig/

Hallensleben, B., 2009, 'Patriarch Kirill and ecumenism', Religion in Eastern Europe XXIX, 15-18.

Hohmann, C., 2011, Auf getrennten Wegen. Lutherische Missiosn- und Siedlergemeinden in Südafrika im Spannungsfeld der Rassentrennung (16521910), Harrassowitz, Wiesbaden.

International Lutheran Council (ILC), 2013, A worldwide association of confessiona Lutheran churches, viewed 25 March 2013, from http://www.ilc-online.org

Jenkins, P., 2002, 'The next Christianity', in The Atlantic Monthly, viewed 24 June 2010, from http://www.theatlantic.com/past/docs/issues/2002/10/jenkins.htm

Jenkins, P., 2006, The new faces of Christianity: Believing the bible in the global south, Oxford University Press, New York.

Jenkins, P., 2007, God's continent: Christianity, Islam, and Europe's religious crisis, Oxford University Press, Oxford.

Jenkins, P., 2008a, The lost history of Christianity: The thousand-year golden age of the church in the Middle East, Africa, and Asia-and how it died, HarperOne, San Francisco.

Jenkins, P., 2008b, The next Christendom: The rise of global Christianity, Oxford University Press, New York.

Johnson, A. M. \& Maxfield, J.A. (eds.), 2012, The reformation as christianization, Mohr Siebeck, Tübingen.

Jüngel, E., 1999, Das Evangelium von der Rechtfertigung des Gottlosen als Zentrum des christlichen Glaubens. Eine theologische Studie in ökumenischer Absicht, Mohr Siebeck, Tübingen. PMid:10381487, PMCid:PMC1752912

Kasper, W.K., 2007, 'Ein persönlicher Blick auf die katholische Kirche in der Welt', in B. Stiftung (ed.), Religionsmonitor 2008, pp. 135-142, Gütersloher Verlagshaus, Gütersloh.

Klän, W., 2002, 'Das Augsburgische Bekenntnisals Grundlageeinerneuen Konfessionalisierung in Hessen', LutherischeTheologie und Kirche 26, 114-134.

Klän, W., 2006, 'Aspects of Lutheran Identity', Concordia Journal 32, 133-146.

Klän, W., 2007, 'Einführung zum Symposium "lutherische Identität in kirchlicher Verbindlichkeit"', in W. Klän (ed.), Lutherische Identität in kirchlicher Verbindlichkeit. Erwägungen zum Weg lutherischer Kirchen in Europa nach der Millenniumswende, pp. 15-28, Edition Ruprecht, Göttingen.

Klän, W. \& Da Silva, G. (eds.), 2010, Quellen zur Geschichte selbstständiger evangelisch-lutherischer Kirchen in Deutschland. Dokumente aus dem Bereich konkordien/utherischer Kirchen, Edition Ruprecht, Göttingen. 
Kolb, R., 1991, Confessing the faith: Reformers define the church, 1530-1580, Concordia Publishing House, St. Louis.

Kolb, R., 1993, The Christian faith: A Lutheran exposition, Concordia Publishing House, St. Louis.

Kolb, R., 1999, 'Luther on the two kinds of righteousness. Reflections on his twodimensional definition of humanity at the heart of his theology', Lutheran Quarterly XIII, 449-466.

Kolb, R., 2005, Bound choice, election, and Wittenberg theological method: From Martin Luther to the Formula of Concord, Eerdmans, Grand Rapids.

Kolb, R., 2012, Luther and the stories of God: Biblical narratives as a foundation for Christian living, Baker Academic, Grand Rapids.

Kolb, R. \& Wengert, T.J. (eds.), 2000, The Book of Concord: The confessions of the EVANGELICAL Lutheran Church, Fortress Press, Minneapolis.

Kyrill, Patriarch von Moskau und der ganzen Rus, 2009, Freiheit und Verantwortung im Einklang: Zeugnisse für den Aufbruch zu einer neuen Weltgemeinschaft, Institut für Ökumenische Studien, Freiburg, Schweiz.

Lamprecht, H., 2006, 'Von Mohammed zu Christus: Christliche Mission unte Muslimen in der SELK in Leipzig', in Confessio.de, viewed 27 March 2013, from http://www.confessio.de/cms/website.php?id=/religionheute/weltreligionen/ Islam/von_mohammed_zu_christus.htm

Läufer, T. (ed.), 2005, Verfassung der Europäischen Union, Bundeszentrale für politische Bildung, Bonn.

Lehmann, K. \& Kock, M., 2002, 'Stellungnahme von Präses Kock und Kardinal Lehmann zum Konvent zur Zukunft Europas', in EKD, viewed 07 June 2002, from http:// www.ekd.de/presse/pm66_20

Lexutt, A., 2011, 'Luther und der Islam. Beten und Büßen statt Reden und Kämpfen' Spiegel der Forschung 28, 60-71.

Lund, E., 2008, 'Nordic and baltic Lutheranism', in R. Kolb (ed.), Lutheran ecclesiastical culture, 1550-1675, pp. 411-454, Brill, Leiden/Boston. http://dx.doi.org/10.1163/ ej. $9789004166417 . i-533.49$

Luther, M., [1523] 1962, 'Temporal authority: To what extent it should be obeyed', transl. J.J. Schindel, in W.I. Brandt (rev.), Luther's Works (LW): The Christian in society II, vol. 45, pp. 75-129, Fortress Press, Philadelphia.

Luther, M., [1529] 2000, 'The Large Catechism, The Creed III', in R. Kolb \& T.J. Wenger (eds.), The Book of Concord: The confessions of the Evangelical Lutheran Church, pp. 377-480, Fortress Press, Minneapolis.

Lutheran Church in Southern Africa (LCSA), Homepage, 25 March 2013, from https:// sites.google.com/site/lutheranchurchinsouthernAfrica/

Müller, O. \& Pollack, D., 2007, 'Wie religiös ist Europa? Kirchlichkeit, Religiosität und Spiritualität in West- und Osteuropa', in Bertelsmann Stiftung (ed.) Religionsmonitor 2008, pp. 167-178, Gütersloher Verlagshaus, Gütersloh.

Müller-Graff, P-C. \& Schneider, H. (eds.), 2003, Kirchen und Religionsgemeinschaften in der Europäischen Union, Schriftenreihe des Arbeitskreises Europäische Integration e.V. Band 50, Nomos Verlagsgesellschaft, Baden-Baden.

Nafzger, S. H., 2007, 'The Lutheran understanding of church fellowship and its practice with ecclesiastical accountability: A Missouri Synod perspective', in W. Klän (ed.), Lutherische Identität in kirchlicher Verbindlichkeit. Erwägungen zum Weg lutherischer Kirchen in Europa nach der Millenniumswende, pp. 61-89, Edition Ruprecht, Göttingen.

Nancy, J-L., 2008a, Dekonstruktion des Christentums, transl. E. von der Osten Diaphanes, Zürich \& Berlin. PMCid:PMC2881160

Nancy, J-L., 2008b, Dis-Enclosure: The deconstruction of Christianity, transl. B. Bergo, G. Malenfant \& M.B. Smith, Fordham University Press, New York.

Petzold, M., 2007, 'Intellektuelle Offenheit und religiöse Homogenität? Aufschlüsse über die Situation im Osten Deutschlands', in Bertelsmann Stiftung (ed.) Religionsmonitor 2008, pp. 85-94, Gütersloher Verlagshaus, Gütersloh.

Pollack, D., 2009, Rückkehr des Religiösen?, Mohr Siebeck, Tübingen.

Pollack, D., Borowik, I. \& Jagodzinski, W. (eds.), 1998, Religiöser Wandel in den postkommunistischen Ländern Ost- und Mittelosteuropas, Ergon Verlag, Würzburg.

Reinkowski, M., 2012, 'Wie europäisch soll der Islam in Europa sein?', in A. Heit \& G. Pfleiderer (eds.), Religionspolitik II. Zur pluralistischen Religionskultur in Europo, pp. 153-186, Pano Verlag, Zürich.
Reinstorf, D., 2007, 'The effects of the Leuenberg Agreement in South Africa and the question of Lutheran identity', in W. Klän (ed.), Lutherische Identität in kirchlicher Verbindlichkeit: Erwägungen zum Weg lutherischer Kirchen in Europa nach der Millenniumswende, pp. 134-150, Edition Ruprecht, Göttingen.

Rosin, R., 2007, 'The Lutheran Church - Missouri Synod and Europe', in W. Klän (ed.), Lutherische Identität in kirchlicher Verbindlichkeit: Erwägungen zum Weg lutherischer Kirchen in Europa nach der Millenniumswende, pp. 112-115, Edition Ruprecht, Göttingen.

Rocholl, R., 1881, Einsame Wege, A. Deichert'sche Verlagsbuchhandlung Nachf, Leipzig.

Rublack, H-C. (ed.), 1992, Die lutherische Konfessionalisierung in Deutschland, Gütersloher Verlagshaus, Gütersloh.

Schaef, A.W., 1987, When society becomes an addict, Harper Collins, New York.

Schjørring, J.H., Kumari, P. \& Hjelm, N. (eds.), 1997, Vom Weltbund zur Gemeinschaft. Geschichte des Lutherischen Weltbundes 1947-1997, Lutherisches Verlagshaus, Hannover.

Schön, M., 2011, 'Repressive Religionspolitik und zivilgesellschaftliches Engagement', in A. Liedhegener \& I-J. Werkner (eds.), Religion zwischen Zivilgesellschaft und politischem System. Befunde-Positionen - Perspektiven, pp. 187-210, VS Verlag für Sozialwissenschaften \& Springer Fachmedien, Wiesbaden, http://dx.doi. für Sozialwissenschaften \& Sprin

Silcock, J., 2007, 'Lutheran church of Australia: Bilateral dialogues and selective eucharistic hospitality', in W. Klän (ed.), Lutherische Identität in kirchlicher Verbindlichkeit: Erwägungen zum Weg lutherischer Kirchen in Europa nach der Millenniumswende, pp. 152-167, Edition Ruprecht, Göttingen.

Slenczka, N., 2003, 'Die Bedeutung des Bekenntnisses für das Verständnis der Kirche und die Konstitution der Kirche in lutherischer Sicht', in K. Grünwaldt \& U. Hahn (eds.), Profil - Bekenntnis - Identität: Was lutherische Kirchen prägt, pp. 9-34, Lutherisches Kirchenamt, Hannover.

Stolle, V., 2013, 'Apartheid and the Bleckmar Mission. Lutheran Church Mission in the Federal Republic of Germany', in W. Klän \& G. da Silva (eds.), Mission und Apartheid. Ein unentrinnbares Erbe und seine Aufarbeitung durch lutherische Kirchen im südlichen Afrika, pp. 40-49, Edition Ruprecht, Göttingen.

Taylor, C., 2007, A secular age, Harvard University Press, Cambrigde, MA.

Treaty of Lisbon, 2007, Official Journal of the European Union, C 306, viewed 25 March 2013, from http://europa.eu/lisbon_treaty/full_text/index_en.htm

Vaahtoranta, M., 2005, Ein Gott, ein Mensch, eine Welt: Beiträge zur theologischen Islambegegnung, Elrim, Mannheim. (ELRIM-Heft, 1).

Vaahtoranta, M., 2008, Mission der Liebe. Gottes Dialog mit dem Islam, Elrim, Mannheim. (ELRIM-Heft, 2).

Von Friedeburg, R., 2008, 'Church and state in Lutheran lands, 1550-1675', in R. Kolb (ed.), Lutheran ecclesiastical culture, 1550-1675, pp. 361-410, Brill, Leiden/ Boston. http://dx.doi.org/10.1163/ej.9789004166417.i-533.42

Wenz, G., 1998, Theologie der Bekenntnisschriften der evangelisch-lutherischen Kirche, Walter de Gruyter, Berlin/New York. PMCid:PMC310688

Wohlrab-Sahr, M., 2007, 'Das stabile Drittel jenseits der Religiosität. Religionslosigkeit in Deutschland', in Bertelsmann Stiftung (ed.), Religionsmonitor 2008, pp. 95-103, Gütersloher Verlagshaus, Gütersloh.

Wright, W.J., 2010, Martin Luther's understanding of God's two kingdoms: A response to the challenge of skepticism, Baker Academic, Grand Rapids.

Wüstenberg, R.K., 2004, Die politische Dimension der Versöhnung: Eine systematischtheologische Studie zum Umgang mit Schuld nach den Systemumbrüchen in Südafrika und Deutschland, Gütersloher Verlagshaus, Gütersloh.

Wüstenberg, R.K., 2009, The political dimension of reconciliation: A theological analysis of ways of dealing with guilt during the transitions to democracy in SouthAfrica and Germany, transl. R.H. Lundell, Eerdmans, Grand Rapids/Cambridge.

Zander, H., 2012, 'Religionsfreiheit im Rahmen der Verfassung - ein Assimilationsprojekt?', in A. Heit \& G. Pfleiderer (eds.), Religionspolitik II. Zur pluralistischen Religionskultur in Europa, pp. 127-152, Pano Verlag, Zürich \& Nomos, Baden-Baden.

Zieger, R., 2012, 'Gibt es im Reich Gottes abschließbare Klotüren?', Info aus der Lutherischen Kirchenmission, viewed 25 October, from http:// lutherischekirchenmission.wordpress.com/2012/10/25/gibt-es-im-reich-gottesabschliesbare-kloturen/02_konvent_europazukunft.html 